\title{
Factors affecting production of luciferase and epitope-tagged IGF-I in porcine muscle after DNA injection
}

\author{
R S R Everett ${ }^{1,2}$, D E Gerrard ${ }^{1}$ and A L Grant ${ }^{1}$ \\ ${ }^{1}$ Department of Animal Sciences, Purdue University, West Lafayette, Indiana 47907-1151, USA \\ ${ }^{2}$ Department of Physiological Sciences, University of California, Los Angeles, California, USA \\ (Requests for offprints should be addressed to A L Grant, 1151 Smith Hall, Department of Animal Sciences, Purdue University, West Lafayette, \\ Indiana 47907-1151, USA; Email: agrant@purdue.edu)
}

\begin{abstract}
Direct DNA injection into porcine skeletal muscle was investigated as an approach for studying roles of locally produced IGF-I on IGF-binding protein (IGFBP) production. To determine parameters for maximal reporter gene expression, and to investigate the effects of dose, time and weaning on exogenous DNA expression, plasmid DNA encoding firefly luciferase under control of a constitutive promoter and enhancer was injected in skeletal muscle of pigs. Results indicate that injected DNA does not migrate beyond $9 \mathrm{~mm}$ from injection sites and that $100 \mu \mathrm{g}$ DNA injections resulted in optimal luciferase activity. Maximum amounts of recombinant protein were observed 3 days after injection, and were reduced by weaning. Using these data, a second DNA injection study was performed using
\end{abstract}

plasmid DNA containing a cDNA insert for epitopetagged insulin-like growth factor-I (TIGF-I). Significant quantities of TIGF-I were detected by ELISA and confirmed by western blotting. Both IGFBP-2 and IGFBP-2 mRNA were increased in treated muscle compared with controls. We conclude that increased expression of IGF-I in muscle results in increased IGFBP-2. Furthermore, these data indicate that this in vivo approach of gene transfer results in biologically active recombinant protein production in porcine skeletal muscle, and provides an excellent in vivo model for studying the autocrine and (or) paracrine effects of locally produced growth factors in skeletal muscle.

Journal of Endocrinology (2000) 166, 255-263

\section{Introduction}

Insulin-like growth factors (IGFs) have important roles in the regulation of skeletal muscle growth and development (Florini et al. 1996). Many of the paracrine and autocrine roles of the IGFs, including interactions with the IGFbinding proteins (IGFBPs), have been studied using cells in culture. IGFBPs can stimulate or inhibit IGF-I receptor-mediated IGF activity (Rechler 1993, Zapf 1995). For example, treatment of cultured muscle cells with IGF-I at concentrations to alter growth increases secretion of IGFBPs (McCusker \& Clemmons 1988, McCusker et al. 1989), including IGFBP-2, which is the predominant binding protein secreted by porcine muscle cells (Fligger et al. 1998). Both IGF-I and IGFBPs are developmentally regulated throughout porcine muscle development, but interactions between IGF-I and IGFBP-2 in vivo are not clear (Gerrard et al. 1998, 1999). Klindt et al. (1998) have demonstrated an increase in IGFBP-2 levels in the serum of pigs treated with IGF-I, but the interaction of muscle-derived IGF-I on IGFBP-2 is less clear. Studying interactions of these growth factors in vivo would enable a better understanding of autocrine and paracrine actions in muscle.

Although infusion of peptide is one means of investigating in vivo roles of IGF-I (Adams \& McCue 1998), gene transfer allows local expression of IGF-I in muscle and offers an in vivo model for further study of IGF-I and IGFBP interactions. Recently, Barton-Davis et al. (1998, 1999) used viral-mediated delivery to introduce IGF-I into muscle of mice. An alternative method to viralmediated delivery is direct injection of plasmid DNA, which has been shown to produce a variety of recombinant proteins, including hormones, in several vertebrate species (Wolff et al. 1990, MacColl et al. 1999). Alila et al. (1997) demonstrated localized and sustained production of biologically active recombinant human IGF-I after intramuscular injections of plasmid DNA encoding this protein. Direct injection of DNA into porcine skeletal muscle is a potential large-animal in vivo model for further investigation of the autocrine and paracrine effects that have been observed in vitro. In this study, direct DNA injections of luciferase DNA reporter constructs were used to develop a model for obtaining recombinant protein 
production in porcine skeletal muscle. Factors examined in developing this model were exogenous DNA migration, and effects of DNA dose, time and weaning on recombinant protein production. Subsequently, this model was used for the production of biologically active recombinant epitope-tagged IGF-I in porcine skeletal muscle to examine effects of this IGF-I on IGFBP-2 expression.

\section{Materials and Methods}

\section{Plasmid DNA purification}

Plasmid DNAs used in the present study were pGL3C DNA plasmid (Promega, Madison, WI, USA) containing the luciferase reporter gene under control of the SV40 promoter, and pcDNA3.1(+) (Clontech, Palo Alto, CA, USA) containing the porcine IGF-I cDNA under control of the CMV promoter (epitope-tagged IGF-I, TIGF-I). The IGF-I cDNA contains the sequence for the mature IGF-I peptide, signal peptide and carboxy peptide. To enable identification of exogenous IGF-I from the endogenous protein, the amino end of the mature peptide sequence has an 11-amino acid (T7) tag that is detected by an anti-T7 antibody. Reichel et al. (1998, 2000) have demonstrated that this DNA vector produces biologically active recombinant IGF-I in muscle cell cultures. Plasmid DNA was isolated using a Wizard Plus Maxipreps DNA purification system (Promega).

\section{Intramuscular plasmid DNA injections}

Plasmid pGL3C DNA $(100 \mu \mathrm{g}, 200 \mu \mathrm{g}$ and $500 \mu \mathrm{g})$ was resuspended in $250 \mu \mathrm{l}$ sterile saline $(0.9 \% \mathrm{NaCl})$ containing $1 \%$ india ink. Hair was removed from skin overlying the longissimus muscle and injection sites marked with a tattoo gun. Plasmid DNA was injected intramuscularly with 27 G1/2 needles (Becton Dickinson, Franklin Lakes, NJ, USA).

\section{Experimental design for luciferase injections}

Crossbred pigs (7 days of age) were obtained from the Purdue University Research and Education Center. All procedures were approved by the Purdue University Animal Care and Use Committee. Nine pigs were used in the first study to determine the migration of injected DNA and/or recombinant protein at various doses and times after injection, and 24 pigs were injected in the second study to determine the effects of DNA dose, time and weaning on recombinant protein expression. Each pig received a total of four injections in the longissimus muscles at 7 days of age. The right muscle was injected with 100 and $200 \mu \mathrm{g}$ plasmid DNA, whereas the left muscle was injected with $500 \mu \mathrm{g}$ and $0 \mu \mathrm{g}$ plasmid. In the first study $(n=9)$, pigs were left with the sow, and three pigs per time were killed at 10, 17 and 24 days after injection. Injected areas of the muscle were located using the presence of the india ink. Samples were collected and weighed. Five $3-\mathrm{mm}$ samples $(15 \mathrm{~mm}$ wide $\times 16.5 \mathrm{~mm}$ deep) anterior (sites -1 to -5 ) to the injection site (site 0 ) and five 3-mm samples posterior (sites 1 to 5 ) to site 0 were collected. In the second study $(n=24)$, pigs were injected at 7 days of age, and three pigs per time that remained with sows were killed at 3, 10, 13, 14, 15 and 17 days after injection. Six injected pigs were weaned 14 days after injection, and three pigs were killed on days 15 and 17 after injection. A single muscle sample $(21 \times 16.5 \times 21 \mathrm{~mm})$ was collected from each injection site. All muscle samples were frozen in liquid nitrogen and stored at $-80{ }^{\circ} \mathrm{C}$ until required for processing.

\section{Experimental design for IGF injections}

Longissimus muscles of six pigs (7 days of age) were injected with $100 \mu \mathrm{g}$ TIGF-I plasmid DNA. Each pig received a total of six injections (two injections of $100 \mu \mathrm{g}$ DNA and one injection of saline alone in each longissimus muscle). Three days after injection, two pigs were killed and muscle samples measuring $21 \times 16.5 \times 21 \mathrm{~mm}$ were collected from treated and control injection sites. Two pigs were weaned 3 days after injection and two pigs were left with the sow. These remaining four pigs were killed 4 days after injection and muscle samples were collected for further analysis. Samples were frozen in liquid nitrogen and used for ELISA, IRMA, and western, ligand, and northern blot analyses. Serum was harvested from blood collected during tissue collection.

\section{Preparation of muscle homogenates}

Frozen muscles were pulverized into a fine powder using a mortar and pestle. Ground muscle was suspended in $500 \mu \mathrm{l}$ homogenization buffer $(25 \mathrm{mM}$ Tris base, $5.7 \mathrm{mM}$ CDTA, $10 \%$ glycerol, $2 \mathrm{mM}$ dithiothreitol, $1 \mathrm{mM}$ phenylmethylsulfonyl fluoride, $1 \mathrm{mM}$ EDTA, $10 \mu \mathrm{g} / \mathrm{ml}$ aprotinin, $10 \mu \mathrm{g} / \mathrm{ml}$ leupeptin). Samples were vortexed and subjected to three freeze-thaw cycles using liquid nitrogen and a $37^{\circ} \mathrm{C}$ water bath. Samples were then centrifuged at $10000 \mathrm{~g}$ for $5 \mathrm{~min}$ and supernatants containing muscle extracts were transferred to microfuge tubes and stored at $-80^{\circ} \mathrm{C}$. Total protein was determined using a bicinchoninic assay (Sigma Chemical Co., St Louis, MO, USA)

\section{Luciferase assay}

Luciferase content was determined using an automated microplate luminometer. Luciferase substrate (Promega) was added by the dispenser unit of the luminometer to an aliquot of muscle extract. Relative light units (RLU) were recorded $2 \mathrm{~s}$ after addition of substrate. All samples 
(20 $\mu$ l volume) were assayed in triplicate. The amount of luciferase in muscle extracts was calculated from RLUs using a standard curve with known quantities of purified firefly luciferase (Boehringer Mannheim Biochemicals, Indianapolis, IN, USA). Data are presented as total amount of luciferase per injection site sample.

\section{Western blot analysis}

Muscle extracts containing $10 \mu \mathrm{g}$ total protein were subjected to SDS-PAGE (15\% polyacrylamide for luciferase samples; $10 \%$ polyacrylamide for TIGF-I samples). Proteins were electrotransferred to membranes (Protran, Schleicher and Schuell, Keene, NH, USA for luciferase; Hybond, Amersham, Arlington Heights, IL, USA for TIGF-I). Membranes were dried and incubated at $4{ }^{\circ} \mathrm{C}$ in $5 \%$ non-fat dry milk (NFDM) reconstituted in phosphatebuffered saline (PBS). After incubation, membranes were washed three times with PBS containing $0 \cdot 1 \%$ Tween-20 and incubated in a 1:200 dilution of rabbit $\alpha$-luciferase polyclonal antibody (Sigma) for $1 \mathrm{~h}$ at room temperature or in a 1:200 dilution of $\alpha$-T7 monoclonal antibody (Novagen, Madison, WI, USA) or $\alpha$-IGF-I monoclonal antibody (Oncogene Science, Cambridge, MA, USA) in $5 \%$ NFDM/PBS overnight at $4{ }^{\circ} \mathrm{C}$. Membranes were washed three times with PBS plus Tween and incubated with a donkey $\alpha$-rabbit antibody coupled to horseradish peroxidase (Jackson Immuno Research Labs, West Grove, PA, USA) at a dilution of 1:10 000 (for luciferase) or a donkey $\alpha$-mouse antibody coupled to horseradish peroxidase (Jackson Immuno Research Labs) at a dilution of 1:5000 (for TIGF-I) for $1 \mathrm{~h}$ at room temperature. Membranes were then washed three times with PBS plus Tween and three times with PBS, and then incubated briefly with a mixture containing equal volumes of enhanced chemiluminescence (ECL) reagents 1 and 2 (Amersham). Membranes were exposed to hyperfilm ECL (Amersham) for visualization of recombinant luciferase and TIGF-I.

\section{TIGF-I ELISA}

ELISA plates were coated with $10 \mu \mathrm{g}$ total protein or $50 \mu \mathrm{l}$ serum in binding buffer $(0.5 \mathrm{M}$ Tris, $\mathrm{pH} 8.5)$ overnight. After washing $(0.05 \mathrm{M}$ Hepes, $0.15 \mathrm{M} \mathrm{NaCl}, 0.05 \%$ Tween, pH 7.4), the wells were blocked ( $3 \%$ NFDM in $0.05 \mathrm{M}$ Hepes) for $15 \mathrm{~min}$ at room temperature. Incubation with primary antibodies was performed for $1 \mathrm{~h}$ at $37^{\circ} \mathrm{C}$. After washing, the wells were incubated with an alkaline phosphatase-conjugated secondary antibody $(1: 2500)$ for $1 \mathrm{~h}$ at $37^{\circ} \mathrm{C}$. Wells were washed, $p$-nitrophenylphosphate phosphatase substrate ( $p$-Nitrophenylphosphate Phosphatase Substrate System, Kirkegaard and Perry Laboratories, Gaithersburg, MD, USA) was added and the wells were incubated for 30 to 45 min. Absorbance was recorded at a wavelength of $405 \mathrm{~nm}$ using a microtiter plate reader. Samples were analyzed in triplicate. The amount of TIGF-I was calculated from a standard curve with known quantities of purified TIGF-I.

\section{Total IGF-I assay}

Total IGF-I in serum and muscle extracts from treated and control sites was quantified by IRMA after acidethanol extraction (Diagnostic Systems Laboratories, Inc., Webster, TX, USA). Samples were analyzed in duplicate and the amount of IGF-I determined from a standard curve with known quantities of IGF-I.

\section{Ligand blotting of IGFBP-2}

Western ligand blotting was performed using procedures described by Fligger et al. (1998). Samples (equivalent to $15 \mu 1$ muscle homogenate) were subjected to SDS-PAGE and proteins were electrotransferred to membrane (Amersham). Blots were briefly air-dried and incubated at $4{ }^{\circ} \mathrm{C}$ with solutions of Tris/saline $(0.1 \mathrm{M}$ Tris, $1.5 \mathrm{M}$ $\mathrm{NaCl}, 0 \cdot 2 \%$ sodium azide) containing nonidet P-40 (3\%), BSA (1\%) and Tween-20 (0.1\%) for 30, 120 and $10 \mathrm{~min}$, respectively. Radiolabeled IGF-I (Amersham) was diluted to a concentration of 100000 c.p.m. $/ \mathrm{ml}$ in hybridization solution containing saline, Tween-20 (0.1\%) and BSA (1\%) and blots were incubated at $4{ }^{\circ} \mathrm{C}$ overnight. Blots were washed twice with saline containing $0 \cdot 1 \%$ Tween20 , followed by three washes with saline only. Blots were then air-dried and autoradiographed for 2-6 days. Relative intensities of the bands in the resulting autoradiographs were quantified by densitometric analysis (Kodak Digital Science 1D, v. 2.0.1 Network Edition, New Haven, CT, USA).

Bands on ligand blots were confirmed to be IGFBP-2 by performing both ligand and western blot analyses on a separate single blot. After transfer, the blot was cut into two strips. One strip was analyzed by western blotting using a rabbit $\alpha$-bovine IGFBP-2 polyclonal antibody (Upstate Biotechnology Institute, Lake Placid, NY, USA) and procedures described above. The second strip was subjected to ligand blotting. This procedure confirmed that the $32 \mathrm{kDa}$ protein visualized on ligand blots was immunoreactive to IGFBP-2 antibody.

\section{Northern blot analysis of IGFBP-2 $m R N A$}

Northern blot analysis was performed as described by Gerrard et al. (1999), with the following modifications. RNA $(40 \mu \mathrm{g})$ from muscles injected with DNA or saline only was subjected to electrophoresis and transferred to membrane (Amersham) and crosslinked (UV Stratalinker, Stratagene, La Jolla, CA, USA). After prehybridization, hybridization was performed using a 585-bp fragment (corresponding to nucleotides 502-1087) from the coding region of a rat IGFBP-2 cDNA (obtained from Dr M Rechler, NIH, Bethesda, MD, USA; Brown et al. 1989) 


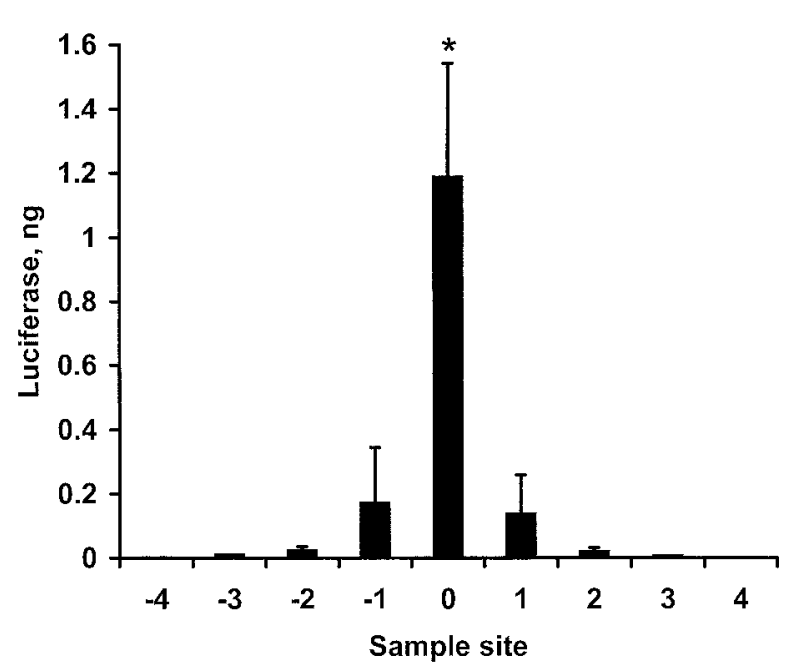

Figure 1 Amount of luciferase (means \pm S.E.) in muscle homogenate 10 days after injection of muscle with $100 \mu \mathrm{g}$ plasmid (pGL3C) DNA. Five incremental 3-mm sites anterior (sites -1 to -4 ) to site 0 (injection site) and five $3-\mathrm{mm}$ sites posterior (sites 1 to 4 ) to site 0 were analyzed for total amount of luciferase. Each bar represents muscle samples from three pigs $\left({ }^{*} P<0 \cdot 0001\right)$.

labelled with $\left[{ }^{32} \mathrm{P}\right]$ (Megaprime DNA labeling system, Amersham). After hybridization, blots were washed and subjected to autoradiography for 5-7 days. Autoradiographs were subjected to densitometric analysis (Kodak Digital Science 1D, v. 2.0.1 Network Edition, New Haven, CT, USA). Blots were subsequently stripped and rehybridized using a $\left[{ }^{32} \mathrm{P}\right]$-labelled $18 \mathrm{~S}$ riboprobe (Ambion, Austin, TX, USA) to confirm equivalent loading and transfer of RNA among lanes.

\section{Statistical analysis}

To determine the effect of dose, time, weaning, and interactions on recombinant gene expression, data from ELISA, IRMA, and image analysis of ligand and northern blots were analyzed using the General Linear Model procedure and Student-Newman-Keuls test of the Statistical Analysis System (SAS 1996).

\section{Results}

Migration, dose and time-course analysis of luciferase

To determine procedures for muscle sampling that would allow for accurate assessment of recombinant protein production, a study on the migration of injected DNA was conducted using a luciferase reporter gene. Total luciferase per muscle sample was dependent on sample site $(P<0 \cdot 0001$; Fig. 1$)$, but migration was not dependent on time or dose $(P>0 \cdot 10)$. For injections of $100 \mu \mathrm{g}$ DNA

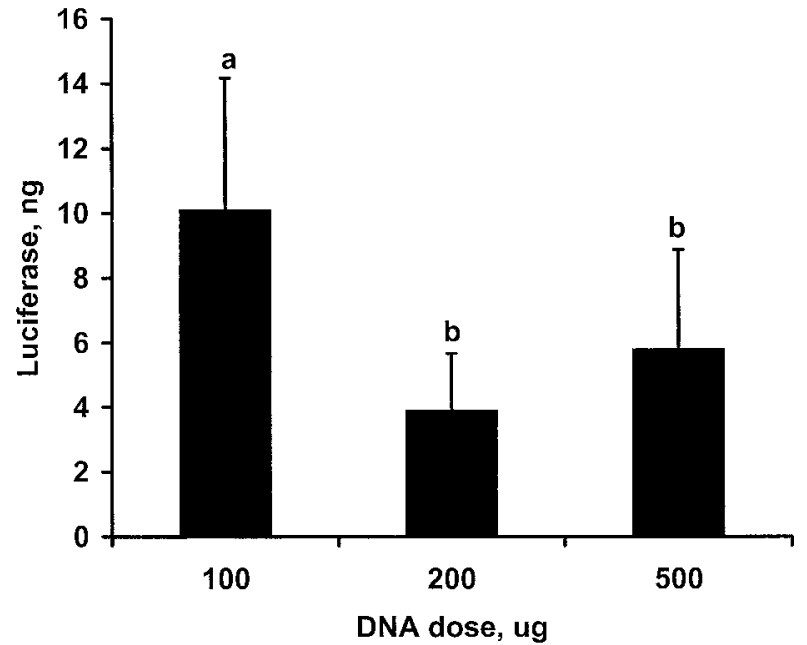

Figure 2 Amount of luciferase (means \pm S.E.) in muscle homogenates 3 days after injection with 100, 200 and $500 \mu \mathrm{g}$ plasmid ( $p$ GL3C) DNA. Each bar represents muscle samples from three pigs. Bars with different letters ( $a$ or $b$ ) are different $(P<0 \cdot 0001)$.

(dose with greatest luciferase, $P<0 \cdot 0001$ ), anterior $(-1)$ and posterior (1) sites immediately adjacent to the injection site (site 0 ) contained only $11-14 \%$ of the luciferase found at site 0 where its activity was greatest $(P<0 \cdot 0001)$. The majority of luciferase (>99\%) was present within three sites of the injection site (sites $-3,-2,-1,0,1,2$, and 3; equal to $21 \mathrm{~mm}$ ). Beyond three sites $(9 \mathrm{~mm})$ on either side of the injection sites, luciferase was less than $1 \%$ of that observed at site $0(P<0 \cdot 0001)$. No luciferase was detected in sites -5 and 5 . For all subsequent studies, muscle samples measuring $21 \mathrm{~mm}$ in length $\times 16.5 \mathrm{~mm}$ deep (depth of longissimus muscle) $\times 21 \mathrm{~mm}$ wide were collected for analyses.

To determine optimal amounts of plasmid DNA for greatest production of recombinant protein, dose-response experiments were conducted using 100, 200 and $500 \mu \mathrm{g}$ pGL3C. Dose response was not dependent on time (no dose $\times$ time interaction; $P>0 \cdot 10)$. Greatest $(P<0 \cdot 0001)$ luciferase activity was observed with injections of $100 \mu \mathrm{g}$ DNA (Fig. 2). Greatest $(P<0 \cdot 01)$ luciferase activity was observed at 3 days after injection with $100 \mu \mathrm{g}$ injections of plasmid pGL3C (Fig. 3). Peak expression of about $10 \cdot 1 \mathrm{ng}$ observed at 3 days after injection declined markedly $(P<0 \cdot 01)$ to $3.3 \mathrm{ng}$ by 10 days after injection, and did not change $(P>0 \cdot 10)$ thereafter to 17 days after injection.

\section{Effect of weaning on luciferase production}

To evaluate the effect of weaning on recombinant protein production, a comparison of luciferase activity in weaned and non-weaned pigs was conducted. Weaning had a 


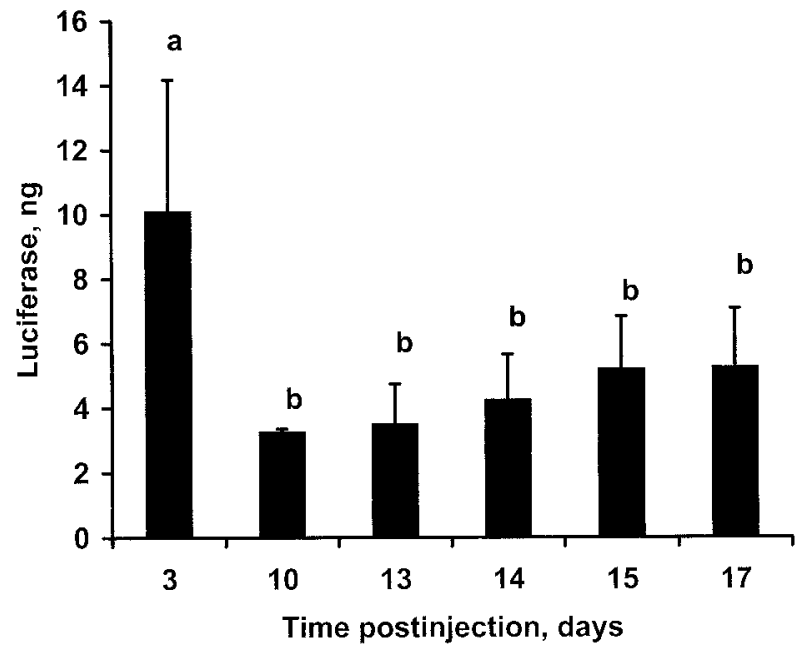

Figure 3 Amount of luciferase (means \pm S.E.) in muscle homogenates at different times after injection with $100 \mu \mathrm{g}$ plasmid (pGL3C) DNA. Each bar represents muscle samples from three pigs. Bars with different letters (a or b) are different $(P<0 \cdot 01)$.

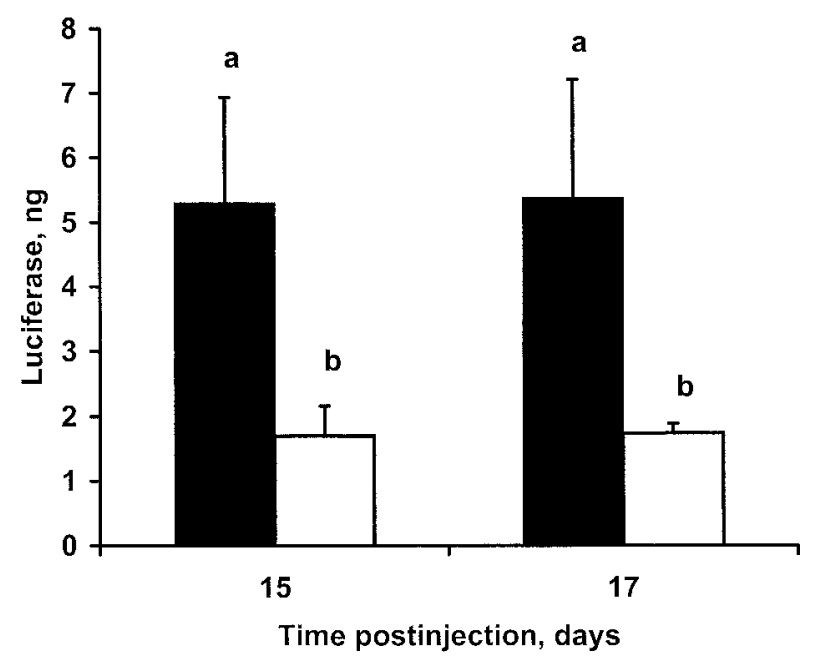

Figure 4 Amount of luciferase (means \pm S.E.) in muscle homogenates 15 and 17 days after injection with $100 \mu \mathrm{g}$ plasmid (pGL3C) DNA. Pigs were weaned ( $\square$ ) 14 days after injection or were left with the sow $(\boldsymbol{\square})$. Each bar represents muscle samples from three pigs. Bars with different letters ( $\mathrm{a}$ or $\mathrm{b})$ are different $(P<0 \cdot 001)$.

negative effect $(P<0 \cdot 001)$ on exogenous DNA expression (Fig. 4). In pigs weaned at 21 days of age and killed 1 day later (15 days after injection), the amount of luciferase activity was $1.72 \mathrm{ng}$, compared with $5.26 \mathrm{ng}$ in nonweaned pigs. Similar differences were observed 17 days after injection. This negative effect of weaning on recombinant luciferase production was further confirmed by western blotting, using homogenates from muscles injected with $100 \mu \mathrm{g}$ pGL3C DNA (data not shown).

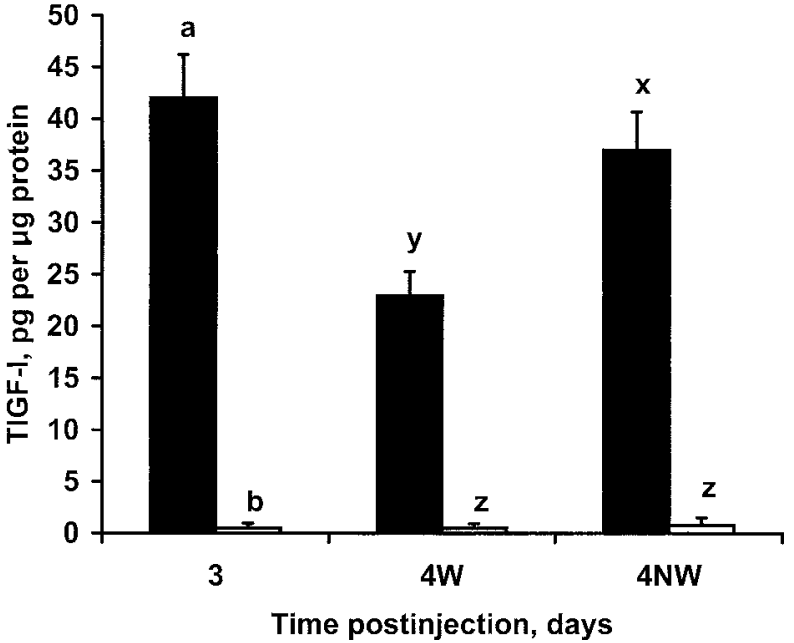

Figure 5 Amount (means \pm S.E.) of epitope-tagged IGF-I (TIGF-I) in muscle homogenate $(1.0 \mu \mathrm{g}$ protein equivalent) from plasmid (TIGF-I) DNA-injected ( $\square$ ) and saline-injected ( $\square$ ) sites. Each bar represents three pigs (four DNA sites and two control sites/pig). Pigs were weaned (W) 4 days after injection or remained with the sow (NW). Bars with different letters ( $a, b$ for day $3 ; x, y$ and $z$ for day 4$)$ are different $(P<0 \cdot 01)$.

\section{Quantification of TIGF-I}

TIGF-I was detected by the ELISA in all treated muscle homogenates (Fig. 5), whereas no significant TIGF-I was detected in control muscle. Furthermore, weaned pigs had lower $(P<0 \cdot 01)$ amounts of TIGF-I than non-weaned animals. Western blotting confirmed these findings and confirmed that the T7 antibody was specific for TIGF-I (data not shown). Recombinant IGF-I could not be detected in sera of injected animals.

To determine if the synthesis of TIGF-I in treated muscle contributed to an increase in total IGF-I concentrations, an IGF-I IRMA using an IGF-I polyclonal antibody was performed on both treated and control muscle homogenates. Amount of IGF-I was greater $(P<0 \cdot 01)$ in muscle extracts from DNA-injected sites than from saline-injected sites (Fig. 6). These data indicate that the recombinant protein synthesized in muscle as a result of direct injections contributes to a significant increase in total IGF-I concentrations in treated sites. In fact, this increase in total IGF-I is accounted for by TIGF-I (compare Figs 5 and 6). As was observed with the ELISA data, there was a decrease $(P<0 \cdot 0001)$ in total IGF-I in treated muscle of weaned animals compared with that of non-weaned pigs.

\section{Quantification of IGFBP-2}

Densitometric analysis of ligand blots show greater $(P<0 \cdot 01)$ amounts of IGFBP-2 in treated muscle as compared with controls (Figs 7 and 8). Abundance of 


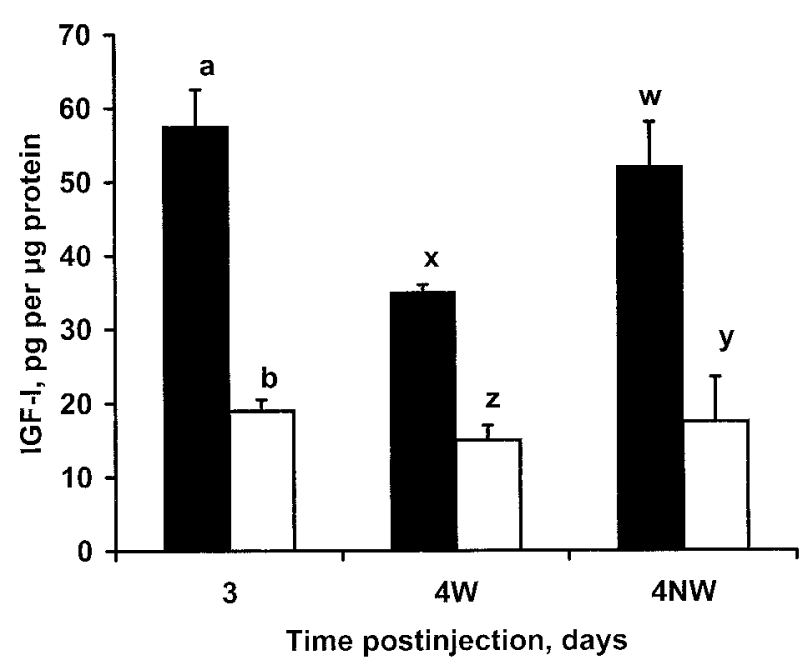

Figure 6 Amount of total IGF-I (means \pm S.E.) in muscle homogenate $(1.0 \mu \mathrm{g}$ protein equivalent) from plasmid (TIGF-I) DNA-injected $(\boldsymbol{\square})$ and saline-injected $(\square)$ sites. Each bar represents three pigs (four DNA sites and two control sites/pig). Pigs were weaned (W) 4 days after injection or remained with the sow (NW). Bars with different letters ( $a, b$ for day $3 ; \mathrm{w}, \mathrm{x}, \mathrm{y}$ and $\mathrm{z}$ for day 4$)$ are different $(P<0 \cdot 01)$.
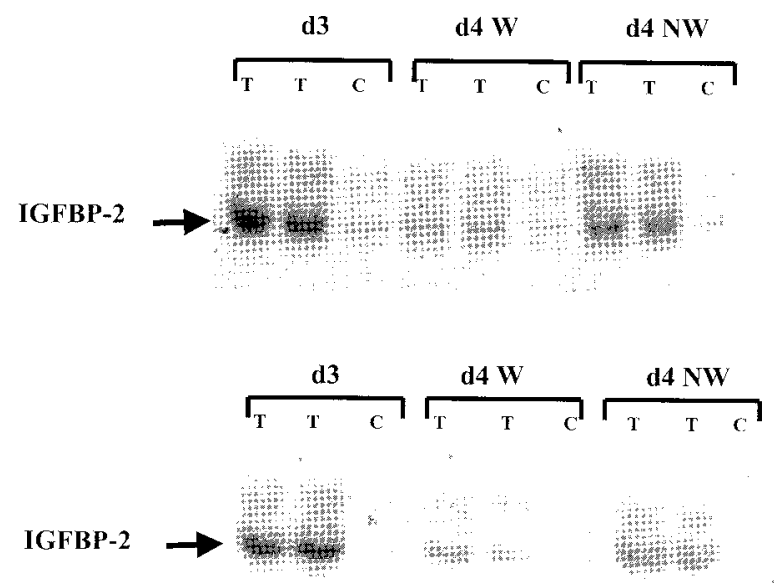

Figure 7 Representative ligand blots of IGFBP-2 in muscle homogenate from plasmid (TIGF-I) DNA-injected (treated, T) and saline-injected (control, C) muscles of weaned (W) and nonweaned (NW) pigs at $3(\mathrm{~d} 3)$ and $4(\mathrm{~d} 4)$ days after injection.

IGFBP-2 was very low in control samples and undetectable in control samples from weaned pigs. The induction of IGFBP-2 was also less in weaned pigs than in nonweaned pigs. TIGF-I treatment and weaning had similar effects on IGFBP-2 mRNA (Figs 9 and 10).

\section{Discussion}

Because recombinant luciferase is easily detected in mammalian tissues in the absence of endogenous luciferase,

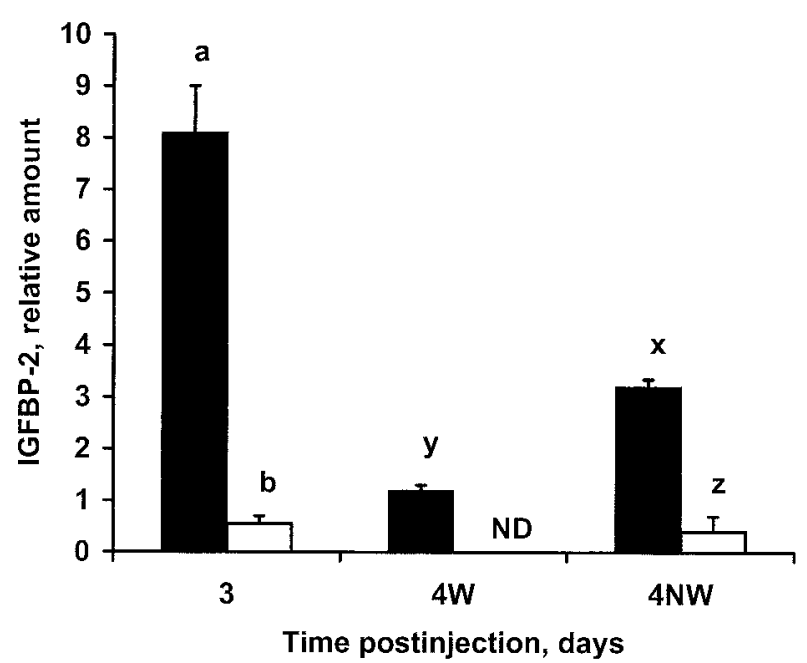

Figure 8 Relative amounts of IGFBP-2 (means \pm S.E.) in muscle homogenate from plasmid (TIGF-I) DNA-injected ( $\boldsymbol{\square})$ and salineinjected $(\square)$ sites as determined by densitometric analysis of ligand blots. Each bar represents three pigs (four DNA sites and two control sites/pig). Pigs were weaned (W) 4 days after injection or remained with the sow (NW). Bars with different letters $(a, b$ for day 3; $x, y$ and $z$ for day 4$)$ are different $(P<0 \cdot 01)$. Band intensities of the weaned control samples were non-detectable (ND).

plasmid pGL3C was used as a reporter gene for obtaining data on DNA migration, and the effect of dose, time and weaning on exogenous DNA expression. Our studies on the migration of injected DNA enabled us to develop muscle sampling procedures for subsequent experiments involving muscle injected with plasmid TIGF-I DNA. The finding that less than $1 \%$ luciferase activity was detected beyond $9 \mathrm{~mm}$ on either side of the injection site suggests that most of the injected DNA remains within $21 \mathrm{~mm}$ of the site of injection. Therefore, in the second part of this study, muscle samples measuring $21 \times 16.5 \times 21 \mathrm{~mm}$ were collected and analyzed for the presence of recombinant protein.

DNA dose-response results suggest that the amount of injected DNA is critical for maximum production of the recombinant protein. As greatest expression was obtained with $100 \mu \mathrm{g}$ plasmid DNA, all comparisons between treated and control animals were made using muscle tissue injected with this dose of DNA. It is possible that amounts of DNA greater than $100 \mu \mathrm{g}$ affect muscle osmolarity which, in turn, may affect cellular uptake of plasmid DNA. Time-course analysis showed that, regardless of the DNA dose, there was a decline in luciferase DNA expression from 3 to 10 days after injection. This decreased expression may be due to degradation of injected DNA, as was observed by Manthorpe et al. (1993); thus the amount of DNA that elicits expression may represent only a portion of the DNA that was injected.

Having established optimum conditions for the production of a recombinant protein in porcine skeletal muscle in 


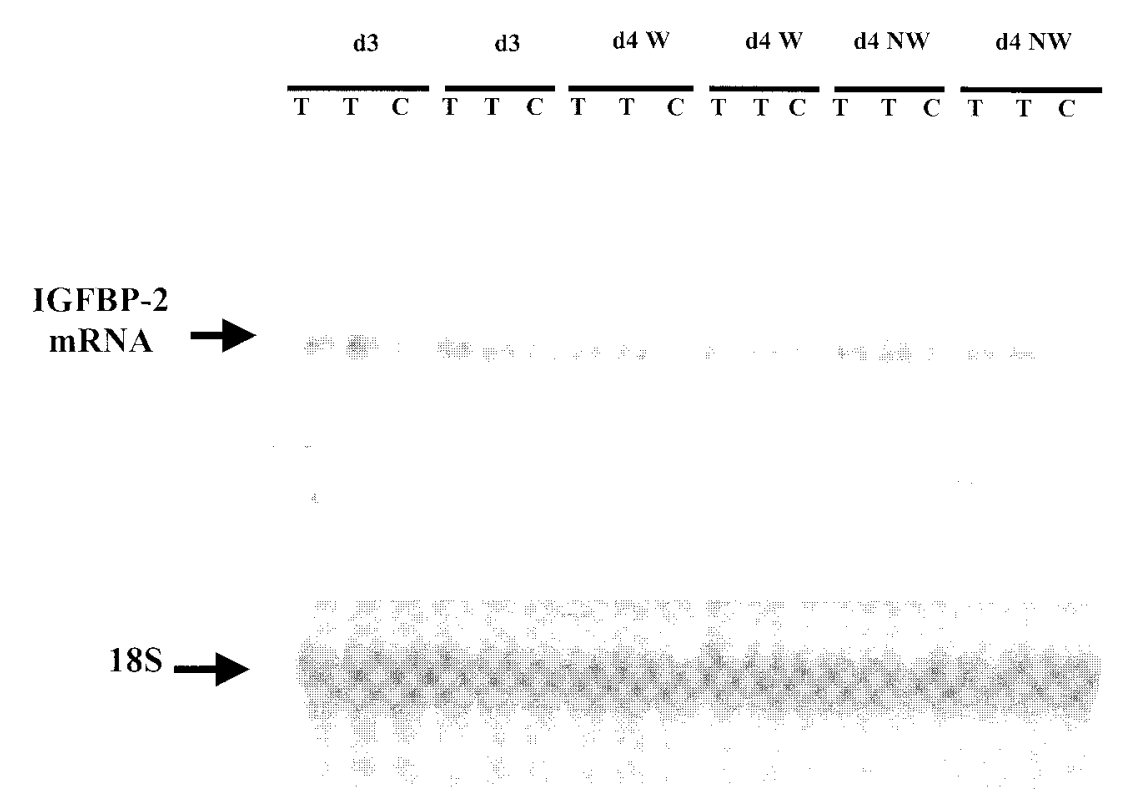

Figure 9 Representative northern blots of IGFBP-2 transcript $(1.3 \mathrm{~kb})$ and $18 \mathrm{~S}$ rRNA in plasmid (TIGF-I) DNA-injected (treated, T) and saline-injected (control, C) muscles of weaned (W) and non-weaned (NW) pigs at $3(\mathrm{~d} 3)$ and $4(\mathrm{~d} 4)$ days after injection.

our previous study, we developed an in vivo injection model for the production of biologically active, epitopetagged, recombinant IGF-I. Our ELISA and IRMA data from treated and control muscle indicates that TIGF-I contributes to a significant increase in total IGF-I found in injected muscle. However, data from the IRMA indicate

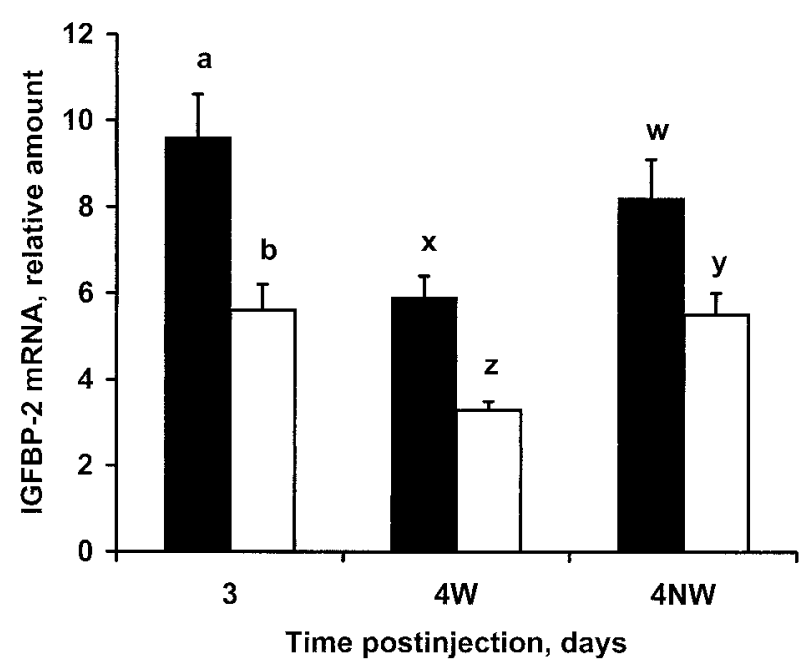

Figure 10 Relative amounts of IGFBP-2 mRNA (means \pm S.E.) in muscle from plasmid (TIGF-I) DNA-injected ( $\mathbf{\square})$ and salineinjected $(\square)$ sites as determined by densitometric analysis of northern blots. Each bar represents three pigs (four DNA sites and two control sites/pig). Pigs were weaned (W) 4 days after injection or remained with the sow (NW). Bars with different letters $(a, b$ for day $3 ; \mathrm{w}, \mathrm{x}, \mathrm{y}$ and $\mathrm{z}$ for day 4$)$ are different $(P<0 \cdot 01)$. that TIGF-I does not appear to increase the concentrations of endogenous IGF-I. The ability of TIGF-I to increase concentrations of IGFBP-2 in injected muscle, as demonstrated by ligand blotting, suggests that this recombinant protein is biologically active. Northern blot analysis confirmed an increase in IGFBP-2 expression in injected muscle.

In the present study, the stimulation of IGFBP-2 by IGF-I suggests an important role for this binding protein in skeletal muscle. Because saline-injected muscle does not show an increase in IGFBP-2, it suggests that trauma (penetration of the muscle with the injection needle) is not a factor that resulted in increased IGFBP-2. To exclude the possibility that exogenous DNA could alter IGFBP-2 concentrations independent of TIGF-I, injections of the vector without the TIGF-I cDNA would serve as a better negative control. Further studies are required to determine the role of IGFBP-2 in skeletal muscle and its interaction with IGF-I.

We consistently observed significant decreases in luciferase, TIGF-I, IGFBP-2 and IGFBP-2 mRNA levels in weaned animals. Carroll et al. (1998) reported significant decreases in endogenous serum IGF-I and IGF-II that accompanied the transient reduction in growth of weaned pigs. These findings indicate that weaning has a negative effect on the production of both exogenous and endogenous proteins. Nutritional status is known to influence the expression and secretion of several growth-related hormones, including GH (Atinmo et al. 1978, Farmer et al. 1992, Straus 1994) and IGF-I (Booth et al. 1994, Weller et al. 1994). Furthermore, animal age at the time of 
weaning may affect the degree to which growth-related endocrine function is altered (Carroll et al. 1998). Nevertheless, the negative effect of weaning on the production of luciferase and TIGF-I in treated muscle suggests that the activity of SV40 and CMV promoters may be sensitive to these nutritional stresses. Experiments on non-weaned animals with reduced food intake would provide information on whether dietary changes have a major role in the weaning effects observed above. Our data show that IGF-I and TIGF-I affect IGFBP-2 levels in muscle. Therefore, lower levels of IGFBP-2 transcripts in weaned animals could be attributable to the decrease in IGF-I and TIGF-I in weaned pigs. The negative effect of weaning on the synthesis of exogenous proteins and the time course required for these proteins to reach normal concentrations after weaning requires further characterization.

The inability to detect TIGF-I in the sera of injected pigs in our study suggests that our DNA injection system offers a method with which to study local production effects of IGF-I without affecting circulating concentrations, which could have undesirable effects on other tissues. Delivery of IGF-I via adeno-associated virus has similar advantages (Barton-Davis et al. 1998). However, direct injection of DNA has been used to alter circulating hormones (MacColl et al. 1999). For example, DraghiaAkli et al. $(1997,1999)$ demonstrated that intramuscular injections of plasmid DNA containing a human growth hormone-releasing hormone cDNA into mice and pigs resulted in increased concentrations of growth hormone in serum, along with increased body growth. Moreover, Anwer et al. (1998) administered intramuscular injections of plasmids for expression of human growth hormone (hGH) and observed long-term expression of biologically active hGH in skeletal muscle and its secretion into the systemic circulation. Perhaps multiple injections of plasmid IGF-I DNA or larger amounts of DNA coupled with electroporation (Draghia-Akli et al. 1999) are required to observe significant concentrations of the recombinant protein in the circulation of larger animals. This would enable further study of the hypothalamic-pituitary-IGF axis in pigs and other large animals.

In summary, we have demonstrated that DNA injection can be used for directing local production of IGF-I in porcine muscle, and that an epitope tag allows recombinantly synthesized exogenous IGF-I to be distinguished from endogenous IGF-I. More specifically, we have demonstrated that locally produced IGF-I increases IGFBP-2 production in muscle. We have also shown that production of recombinant proteins decreases during weaning. This technique of direct injections of DNA into skeletal muscle, resulting in the localized production of a recombinant protein, provides an excellent model for studying the autocrine and (or) paracrine effects of hormones and proteins that have roles in muscle growth and development.

\section{Acknowledgements}

Paper No. 16,169 of the Purdue Agricultural Research Programs, Purdue University. This research was funded, in part, by the National Pork Board in cooperation with the National Pork Producers Council.

\section{References}

Adams GR \& McCue SA 1998 Localized infusion of IGF-I results in skeletal muscle hypertrophy in rats. Journal of Applied Physiology 84 $1716-1722$

Alila H, Coleman M, Nitta H, French M, Anwer K, Liu Q, Meyer T, Wang J, Mumper R, Oubari D, Long S, Nordstrom J \& Rolland A 1997 Expression of biologically active human insulin-like growth factor-I following intramuscular injection of a formulated plasmid in rats. Human Gene Therapy 8 1785-1795.

Anwer K, Shi M, French MF, Muller SR, Chen W, Liu Q, Proctor BL, Wang J, Mumper RJ, Singhal A, Rolland AP \& Alila HW 1998 Systemic effect of human growth hormone after intramuscular injection of a single dose of a muscle-specific gene medicine. Human Gene Therapy 9 659-670.

Atinmo T, Baldijao KA, Houpt KA, Pond WG \& Barnes RH 1978 Plasma levels of growth hormone and insulin in protein malnourished vs normal growing pigs in response to arginine or glucose. Journal of Animal Science 46 409-416.

Barton-Davis ER, Shoturma DI, Musaro A, Rosenthal N \& Sweeney HL 1998 Viral mediated expression of insulin-like growth factor I blocks the aging-related loss of skeletal muscle function. PNAS 95 15603-15607.

Barton-Davis ER, Shoturma DI \& Sweeney HL 1999 Contribution of satellite cells to IGF-I induced hypertrophy of skeletal muscle. Acta Physiologica Scandinavica 167 301-305.

Booth PJ, Craigon J \& Foxcroft GR 1994 Nutritional manipulation of growth and metabolic and reproductive status in prepubertal gilts. Journal of Animal Science 72 2415-2424.

Brown AL, Chiariotti L, Orlowski CC, Mehlman T, Burgess WH, Ackerman EJ, Bruni CB \& Rechler MM 1989 Nucleotide sequence and expression of a cDNA clone encoding a fetal rat binding protein for insulin-like growth factors. Journal of Biological Chemistry 264 5148-5154.

Carroll JA, Veum TL \& Matteri RL 1998 Endocrine responses to weaning and changes in post-weaning diet in the young pig. Domestic Animal Endocrinology 15 183-194.

Draghia-Akli R, Li X \& Schwartz RJ 1997 Enhanced growth by ectopic expression of growth hormone releasing hormone using an injectable myogenic vector. Nature Biotechnology 15 1285-1289.

Draghia-Akli R, Fiorotto ML, Hill LA, Malone PB, Deaver DR \& Schwartz RJ 1999 Myogenic expression of an injectable proteaseresistant growth hormone-releasing hormone augments long-term growth in pigs. Nature Biotechnology 17 1179-1183.

Farmer C, Petitclerc D, Pelletier G, Gaudreau P \& Brazeau P 1992 Carcass composition and resistance to fasting in neonatal piglets born of sows immunized against somatostatin and/or receiving growth hormone-releasing factor injections during gestation. Biology of the Neonate 61 110-117.

Fligger JM, Malven PV, Doumit ME, Merkel RA \& Grant AL 1998 Increases in insulin-like growth factor binding protein-2 accompany decreases in proliferation and differentiation when porcine muscle satellite cells undergo multiple passages. Journal of Animal Science 76 086-2093.

Florini JR, Ewton DZ \& Coolican SA 1996 Growth hormone and the insulin-like growth factor system in myogenesis. Endocrine Reviews 17 481-517. 
Gerrard DE, Okamura CS, Ranalletta MA \& Grant AL 1998 Developmental expression and location of IGF-I and IGF-II mRNA and protein in skeletal muscle. Journal of Animal Science 76 1004-1011.

Gerrard DE, Okamura CS \& Grant AL 1999 Expression and location of IGF binding proteins-2, -4 , and -5 in developing fetal tissues. Journal of Animal Science 77 1431-1441.

Klindt J, Yen JT, Buonomo FC, Roberts AJ \& Wise T 1998 Growth, body composition, and endocrine responses to chronic administration of insulin-like growth factor I and (or) porcine growth hormone in pigs. Journal of Animal Science 76 2368-2381.

MacColl GS, Goldspink G \& Bouloux PMG 1999 Using skeletal muscle as an artificial endocrine tissue. Journal of Endocrinology 162 $1-9$.

McCusker RH \& Clemmons DR 1988 Insulin-like growth factor binding protein secretion by muscle cells: effects of cellular differentiation and proliferation. Journal of Cell Physiology 137 505-512.

McCusker RH, Camacho-Hubner C \& Clemmons DR 1989 Identification of the types of insulin-like growth factor bindingproteins that are secreted by muscle cells in vitro. Journal of Biological Chemistry 264 7795-7800.

Manthorpe M, Cornefert-Jensen F, Hartikka J, Felgner J, Rundell A, Margarth M \& Dwarki VJ 1993 Gene therapy in intramuscular injection of plasmid DNA: studies on firefly luciferase gene expression in mice. Human Gene Therapy 4 419-421.
Rechler MM 1993 Insulin-like growth factor binding proteins. In Vitamins and Hormones, vol 47, pp 1-114. Ed DB McCormick. New York: Academic Press.

Reichel CL, Grant AL, Bidwell CA \& Gerrard DE 1998 Development and biological activity of epitope-tagged porcine IGF-I. Journal of Animal Science 76 (Suppl 1) 128.

Reichel CL, Grant AL, Everett RSR, Bidwell CA \& Gerrard DE 2000 Epitope-tagged insulin-like growth factor-I expression in muscle. Domestic Animal Endocrinology 18 337-348.

SAS 1996 Statistical Analysis System Institute Inc. SAS Users Guide to the Statistical Analysis System. Cary, NC, USA; NC State Univ.

Straus DA 1994 Nutritional regulation of hormones and growth factors that control mammalian growth. FASEB Journal 8 6-12.

Weller PA, Dauncey MJ, Bates PC, Brameld JM, Buttery PJ \& Gilmour RS 1994 Regulation of porcine insulin-like growth factor I and growth hormone receptor mRNA expression by energy status. American Journal of Physiology 266 E776-E785.

Wolff JA, Malone RW, Williams P, Chong W, Ascadi G, Jani A \& Felgner PL 1990 Direct gene transfer into mouse muscle in vivo. Science 247 1465-1468.

Zapf J 1995 Physiological role of the insulin-like growth factor binding proteins. European Journal of Encodrinology 132 645-654.

Received 15 November 1999

Accepted 28 March 2000 